\title{
Technology for America's Economic Growth, A New Direction to Build Economic Strength
}

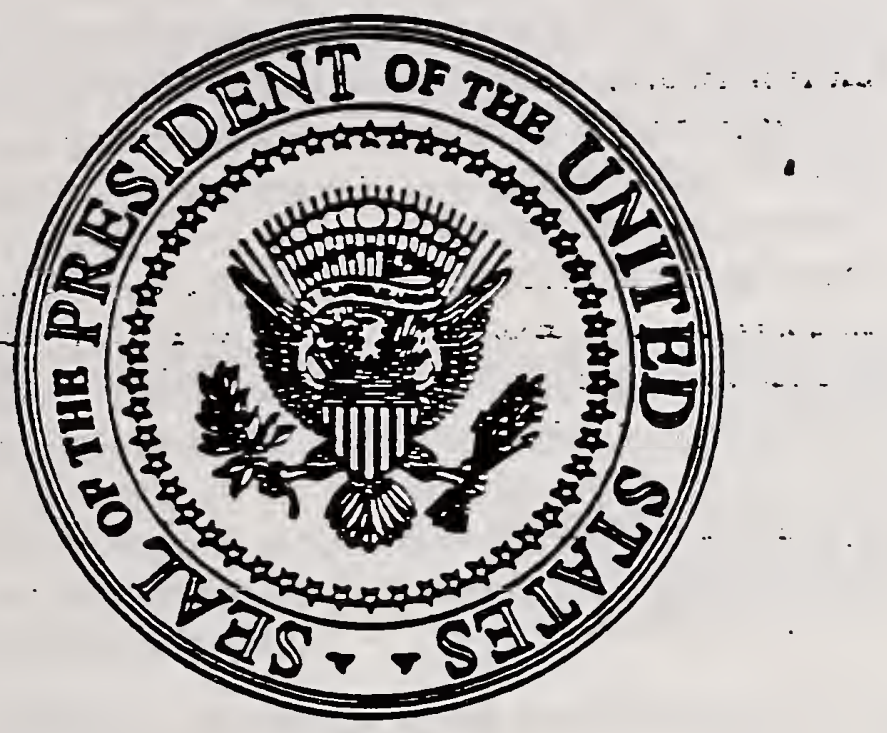

\section{President William J. Clinton Vice President Albert Gore, Jr.}

February 22, 1993

$$
\begin{aligned}
& \text { Bucce - } \\
& \text { There's some } \\
& \text { good stoft on } \\
& \text { This paper. } \\
& \text { Ft土... } \\
& \text { Jeff }
\end{aligned}
$$


Summary: Technology for America's Economic Growth:

A New Direction to Build Economic Strength

GOAL: LONG-TERM ECONOMIC GROWTH THAT CREATES JOBS AND

PROTECTS THE ENVIRONMENT $\ldots . . \ldots \ldots \ldots \ldots \ldots \ldots \ldots \ldots \ldots \ldots \ldots \ldots \ldots \ldots \ldots \ldots . \ldots \ldots$

Technology Development, Commercialization and Use........................... 7

A World-class Business Environment for Innovation and Private Sector Investment.

Education and Training

"Information Superhighways" ........................................................... 16

Transportation and Other Infrastructure .............................................. 18

GOAL: MAKING GOVERNMENT MORE EFFICENT AND MORE

RESPONSTVE .................................................................. 20

Information Technology........................................................... 20

Energy Efficiency ............................................................. 21

Procurement Policy............................................................... 22

GOAL: WORLD LEADERSHIP IN BASIC SCIENCE, MATHIEMATICS, AND

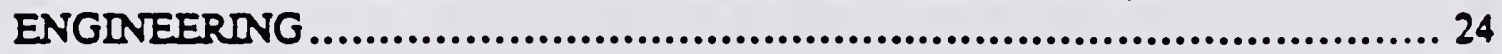

University Research ............................................................... 24

National Laboratories.............................................................. 24

Space Science and Exploration....................................................... 24

Environmental Research ............................................................. 25

BUILDING AMERICA'S ECONOMIC STRENGTH: NEW DNTIATIVES ................. 26

Permanent Extension of the Research and

Experimentation Tax Credit 27

Invest in a National Information Infrastucture .................................... 28

Promote Advanced Manufacturing Technology ..................................... 31

Facilitate Private Sector Development of a New

Generation of Automobiles ........................................................... 33

Improve Technology for Education and Trining ..................................... 35

Investments in Energy-Efficient Federal Buildings .................................. 36 


\section{A Ner Direction}

Investing in technology is investing in America's future: a growing economy with more high-shill, high-wage jobs for American workers; a cleaner environment where energy efficiency increases profits and reduces pollution; a stronger, more competitive private sector able to maintain U.S. leadership in critical world markets; an educational system where every student is challenged; and an inspired scientific and technological research community focused on ensuring not just our national security but our very quality of life.

American technology must move in a new direction to build economic strength and spur economic growth. The traditional federal role in technology development has been limited to support of basic science and mission-oriented research in the Defense Department, NASA, and other agencies. This strategy was appropriate for a previous generation but not for today's profound challenges. We cannot rely on the serendipitous application of defense technology to the private sector. We must aim directly at these new challenges and focus our efforts on the new opportunities before us, recognizing that government can play a key role helping private firms develop and profit from innovations.

We must move in a new direction:

- Strengthening America's industrial competitiveness and creating jobs;

- Creating a business environment where technical innovation can flourish and where investment is attracted to new ideas;

- Ensuring the coordinated management of technology all across the government;

- Forging a closer worbing partnership among industry, federal and state governments, workers, and universities;

- Redirecting the focus of our national efforts toward tochnologies crucial to today's businesses and a growing economy, such as information and communication, flexible manufacturing, and environmental technologies; and,

- Reaffirming our commitment to basic science, the foundation on which all technical progress is ultimately built. 


\section{For the Amerian Papole}

Our most important messure of success will be our ability to make a difference in the lives of the American people, to hamess tochnology so that it improves the quality of their lives and the economic strength of our nation.

We are moving in a new direction that recognizes the critical role technology must play in stimulating and sustaining the long-term economic growth that creates high-quality jobs and provects our environment.

We are moving in a new direction to create an edvacional and training system that challenges American workers to match their stills to the demands of a fast-paced economy and challenges our students to reach for resources beyond their classrooms.

We are moving in a new direction to dramatically improve our ability to transmit complicated information faster and further, to improve our transportition systems, our health care, our research efforts, and even the ability of our military to respond quickly and decisively to any threat to our nation's security.

In these times, technology matters as well to an efficient fam, food processing, and food retailing industry that delivers a variety of low-cost, wholesome foods; to a construction industry that builds high-quality, affordable housing; and to an energy sector thatbalances" energy efficiency with clean, affordable and efficient energy sources.

\section{New Criteria}

We will hold ourselves to tough standards and clear vision. The best technology policy unleashes the creative energies of innovators throughout the economy by creating a market that rewards invention and enterprise. We are moving to accelerate the development of civilian technology with new criteria:

- Accelerating the development of technologies critical for long-term economic growth'but not receiving adequate support from private firms, either because the reurns are too distant or because the level of funding required is too great for individual firms to bear;

- Encouraging a pattern of business development that will likely result in stable, rewarding jobs for large numbers of workers;

- Accelerating the development of technologies that could increase productivity while reducing the burden of economic activity on the local, regional, or global environment; 
- Improving the skills offered by American workers by increasing the productivity and the accessibility of education and training;

- Reflecting the real needs of American businesses as demonstrated by their willingness to share the cost of research or participate in the design of

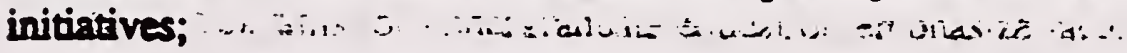

- Supporting communities or disadvantaged groups in the U.S. or abroad who have not enjoyed the benefits of technology-based economic growth;

- Contributing to U.S. access to foreign science and technology, enhancing cooperation on global problems or U.S. successes in technology-related foreign markets.

\section{Reaching Our Technology Goals}

The challenge we face demands that we set and keep focused on our goals:

- LONG TERM ECONOMIC GROWTH THAT CREATES JOBS AND PROTECTS THE ENVIRONMENT

- A GOVERNMENT THAT IS MORE PRODUCTIVE AND MORE RESPONSIVE TO THE NEEDS OF ITS CITIZENS

- WORLD LEADERSEIP IN BASIC SCIENCE, MATHEMATICS, AND ENGINEERNG.

We have the means to stimulate innovations that will bring economic growth and help us reach our goals and other important objectives. Foremost is a sound fiscal policy that reduces the federal deficit and lowers interest rates. But that is not always enough. We must also turn w:

- Research and experimentation tax credits and other fiscal policies to create an environment conducive to innovation and investment;

- A trade policy that encourages open but fair trade;

- A regulatory policy that encourages innovation and achieves social objectives efficiently;

- Education and training programs to ensure continuous leaming opportunities for all Americans; 
- Support for private research and development through research partnerships and other mechanisms to accelerate technologies where market mechanisms do not adequately reflect the nation's return on the investment;

- Support for contract R \& D centers and manufacturing extensión centers that can give small businesses asy access to technical innovations and know-how;

- Support for a national telecommunications infrastucture and other information infrastructures critical for economic expansion;

- Department of Defense and other federal agency purchasing policies designed to foster carly markets for innovative products and services that contribute to national goals;

- Strong and sustained support for basic science to protect the source of future innovations;

- International science and technology cooperative projects that enhance U.S. access to foreign sources of science and tochnology, contribute to the management of global problems, and provide the basis for marketing U.S. goods and services;

- Dual-use Defense Department research and development programs;

- National user facilities that make sophisticated research tools, such a synchrotron radiation and neutron beam tools, available to a variety of research organizations.

\section{Managine Technology for Economic Gronth}

Redirecting America's programs in science and technology will require major changes in the way we manage our efforts. Tight management is essential to ensure the highest possible retum our investments and to ensure that tax, regulatory and other efforts reinforce instead of frustrate our work.

We are making major changes:

- Working with Vice President Gore, a reinvigorated Office of Science and Technology Policy will lead in the development of science and technology policy and will use the Federal Coordinating Council on Science, Engineering, and Technology, along with other means, to coordinate the R \& D programs of the federal agencies;

- The new National Economic Council will monitor the implementation of new policies and provide a forum for coordinating technology policy with the policies of the ur. trade, regulatory, economic development, and other economic sectors.

As we move from traditional, mission-oriented R \& D to investments designed specifically to strengthen America's industrial competitiveness and create jobs, considerable 
care must be taken to set priorities. In many cases, it will be essential to require cost-sharing on the part of private partners. In all cases, it will be essential for our government to work closely with business and labor.

Our initiative in advanced manufacturing; for example, will not be successful without direct input from the private sector about which technical areas are most important. We will conduct a review of laws and regulations, such as the Federal Advisory Committee Act and conflict-of-interest regulations to determine whether ehanges are needed to increase government-industry communication and cooperation.

We also will work closely with Congress to prevent 'eamarking' of funds for science and technology. Peer review and merit-based competition are critical to the success of any science and technology policy.

Effective management of technology policy also requires an effective partnership between federal and state governments. The states have pioneered many valuable programs to accelerate technology development and commercialization. Our. efforts should build on these programs.

And, every federal technology program, including those of long-standing, will be regularly evaluated against pre-established criteria to determine if they should remain part of a national program. Major changes facing our nation's economy demand a searching reexamination of technology programs, particularly now as we move toward new efforts and a new emphasis in our technology for America's economic growth.

\section{Building America's Economic Strength: New Initiatives}

The challenges we face - from our competitors abroad and from our people at home demand dramatic innovation and bold action that will not just revive our economy now but also ensure our economic growth well into the future. Building America's economic strength through technology demands new initiatives that confront these challenges effectively, efficiently, and creatively.

- PERMANENT EXTENSION OF THE RESEARCH AND EXPERMMENTATION TAX CREDIT to sustain incentives for the R\&E work so essential to new developments;

- INVESTMENT IN A NATIONAL INFORMATION DNFRASTRUCTURE and establishment of a task force working with the private sector to design a national communications policy that will ensure rapid introduction of new communication technology;

- ACCELERATED INVESTMENT DN ADVANCED MANUFACTURNG TECHNOLOGIES that promote U.S. industrial competitiveness and that build on, rather than minimize, worker skills; 
- RE-ESTABLISHING TECFDNOLOGICAL LEADERSHIP AND COMPETITTVENESS OF THE U.S. AUTOMOBIE INDUSTRY through a major new program to help the industry develop critical new technology that can all but eliminate the environmental hazards of automobile use and operate from domestically produced fiels and facilitate the development of a new generation of automobiles;

- DMPROVE TECFNOLOGY FOR EDUCATION AND TRAINING by supporting the development and introduction of computer and communications equipment and software that can increase the productivity of learning in formal school settings, a variety of business training facilipies and in homes.

- INVESTMENTS DN ENERGY-EFFICIENT FEDERAL BUILDDNGS to reduce wasteful energy expenses and encourage the adoption of innovative, energy-efficient technology. 


\section{GOAL: LONGTERM ECONOMIC GROWTH THAT CREATES JOBS AND PROTECTS THE ENVIRONMDENT}

Technology is the engine of economic growth. In the United States, technological advance has been responsible for as much as two-thirds of productivity growth since the Depression. Bréalthroughs such as the transistor, tcomputers; recombinant DNA and synthetic materials have created entire new industries and millions of high-paying jobs. .

International competitiveness depends less and less on traditional factors such as access to natural resources and cheap labor. Instead, the new growth industries are knowledge based. They depend on the continuous generation of new technological innovations and the rapid transformation of these innovations into commercial products the world wants to buy. That requires a tented and adaptive work force capable of using the latest tochnologies and reaching ever-higher levels of productivity.

Modern production systems also make much more efficient use of energy and materials. Advances in technology can lead to enormous reductions in the environmental emissions associated with automobiles, buildings, and factories. And because pollution always signals inefficiencies and, because wasteful energy costs raise the price of doing business, these technology advances can also lead to increased profits.

We can promote technology as a catalyst for economic grouth by:

- directly supporting the development, commercialization, and deployment of new technology;

- fiscal and regulatory policies that indirectly promote these activities;

- investment in education and training; and,

- suppor for critical transportation and communication infrastructures.

\section{Technology Development. Commercialization and Use}

Since World War II, the federal government's de facto technology policy has consisted of suppor for basic science and mission-oriented R\&D - hrgely defense technology. Compared to Japan and our other competitors, suppor for commercial technology has been minimal in the U.S.. Instead, the U.S. government has relied on its investments in defense and space to trickle down to civilian industry.

N though that approach to commercial technology may have made sense in an earlier era, when U.S. firms dominated world markets, it is no longer adequate. The nation urgently needs improved strategies for government/industry cooperation in the support of industrial technology. These new approaches need not jeopardize agency missions: In many technology areas, missions of the agencies coincide with commercial interests or can be accomplished better through close cooperation with industry. 
This Administration will modify the ways federal agencies do business to encourage cooperative work with industry in areas of mutual interest. President Eisenhower undertook a similar policy change in 1954, when he issued an executive order directing federal agencies to support basic research. This new policy will result in signifieantly more federal R\&D resources going to (pre-competitive) projects of commercial relevance. - It will also result in federal prograins that go beyond R\&D; where appropriate; to promote the broad application of new rechnology and know-how: in: :e

R\&D. At the level of technology development, the fundamental mechanism for carrying out this new approach is the cost-shared R\&D partnership between government and industry. All federal R\&D agencies (including the nation's 726 federal laboratories) will be encouraged to act as partners with industry wherever possible. In this way; federal investments can be managed to benefit both government's needs and the needs of U.S. businesses.

This reorientation is particularly urgent for the Department of Defense, which accounts for 56 percent of all federal R\&D. A significant portion of DoD's research and development budget is already focused on dual-use projects - particularly projects supported by the Defense Advanced Research Projects Agency (DARPA). Since a growing number of defense needs can be met most efficiently by commercial products and technology. in the years ahead, this fraction will increase. DOD is developing a strategy to improve the integration of defense and commercial tochnology development.

All federal support for lechnology development is being reviewed to ensure that research priorities are in line with contemporary needs of industry and to ensure that strategies for working with industry are consistent.

To strengthen industry-government cooperation and to provide more federal support for commercial R\&D:

- The ratio of civilian and duat-use R\&D to purely military R\&D is significantly higher in President Clinton's economic plan. This is a first step toward balancing funding levels for these two categories. In 1993, the civilian share of the total federal R\&D budget was approximately $41 \%$. Under President Clinton's plan, the civilian share will be more than $50 \%$ by 1998 . Total spending for civilian R\&D will rise from $\$ 27.9$ billion to 36.6 billion during this period.

- The Commerce Department's Adranced Technology Program is expanded signiriontly. Established in 1990, the ATP shares the costs of industry-defined and industry-led projects selected through merit-based competitions.

The Defense Adranced Research Projects Agency (DARPA) will be renamed the Adranced Research Projects Agency (ARPA) - as the agency was known before 1972. The ARPA program in dual use will be expanded in 
ways that increase the likelihood that defense research can lead to civilian product opportunities.

- New Department of Energy programs designed to increase the productivity of energy use io todustry, transportation, and bujtings as well is renenable enerzy programs will ensure that the goals of environmental protection are fully consistent with other business objectives. DOE, working with other agencies, will encourage industry $k \&$ consortia in an effor directed at reducing pollution and manufacturing waste.

Manufacturing R\&D will receive particular attention from ATP, ARPA and other federal agencies. SEMATECH, an industry conso'trium created to develop semiconductor inanufactiring tochnology, will receive continued matching funds from the Department of Defensie in FY94. This consortium an serve as a model for federal consortia funded to advance other critical technologies. Programs will be encouraged in the development of a new automobile, new construction technologies, iñtelligent control and sensor technologies, rapid prototyping, and environmentally-conscious manufacturing.

All laboratories managed by the Departiment of Eneray, NASA, and the Department of Defense that can make a productive contribution to the civilian economy will be reviewed with the aim of devoting at least 10-20 percent of their budgets to R\&D partnerships with industry.

Agencies will make it a priority to remore obstacles to Cooperative R\&D Agreements (CRADAs) and to facilitate industry-lab cooperation through other means.

- The Federal Coordinating Council for Science, Engineering, and Technology (FCCSET) will be strengthened. Initiatives are currently underway in the following six areas: improving our understanding of the climate system, advanced supercomputers and computer networts, math and science education, materials processing, biotechnology, and advanced manufacturing.

Commercialization. Nthough U.S. firms remain relatively strong in the invention of new technologies, foreign competitors are often first to commercialize and bring new products to market. The reorientation of federal R\&D can play an important role. Cooperative research is a powerful way to get technology and know-how into the hands of businesses that are in a position to put them quickly to work. The tax, regulatory, and other reforms described later also play a key role by creating a favorable investment environment for innovation. But in many cases additional programs are needed, such as:

- Regional Technology Alliances explicitly designed to promote the commercialization and application of critical technologies in which there are regional clusters of strength to encourage firms and research institutions within a 
particular region to exchange information, share and develop technology, and develop new products and markets.

Agile Manufacturing programs expanded to allow temporary networks of complementary firms to come together quickly to exploit fast-changing market opportunities. These programs support the development and dissemination of information technology and technical standards to make such networks possible.

Access and Use. In addition to support for the development and adoption of new technologies, programs are needed to ensure that all American businesses have easy access to existing technology and best practices. The Agriculture Department has historically devoted half of its R\&D budget to the active dissemination of research results: The extraordinary productivity gains in American farming throughout this century owe a great deal to the close links between individual farmers and county extension agents.

American manufacturing also needs an effective system. New manufacturing technologies and approaches are available that can lead to dramatic improvements in product quality, cost, and time-to-market. But relatively few U.S: businesses have taken advantage of these new technologies and best practices. The problem is particularly acute among the 360,000 small and medium-sized manufacturers, many of whom are still using 1950 s tochnology.

Workers should play a significant role in the use and spread of manufacturing tochnology. Workplace experience makes clear that new technologies are implemented most effectively when the bnowledge and concerns of workers are included in the process.

To enhance the use of and access to technology, we will:

- Create a mational petwork of manufacturing extension centers. Existing state and federal manufacturing extension centers managed through the Department of Commerce provide assistance to a small number of businesses, but service must be greatly expanded to give all businesses access to the technologies, testing facilities, and training programs they need. Federal funds (to be matched by state and docal governments) will support and build on existing state, local, and university programs, with the goal of creating a nation-wide network of extension centers.

- Expand the Manufacturing Experts in the Clasroom program to support manufacturing specialists from industry and labor teaching in technical and community colleges. The goal is to strengthen the capacity of such institutions to serve regional manufacturing firms.

- Work through the Department of Labor to assist US firms in implementing the principles of high performance work organization. DOL will coordinate assistance in workforce literacy, technical training, labor management relations, 
and the restructuring of management and work processes. Implementation will cocur in part through the network of manufacturing extension centers.

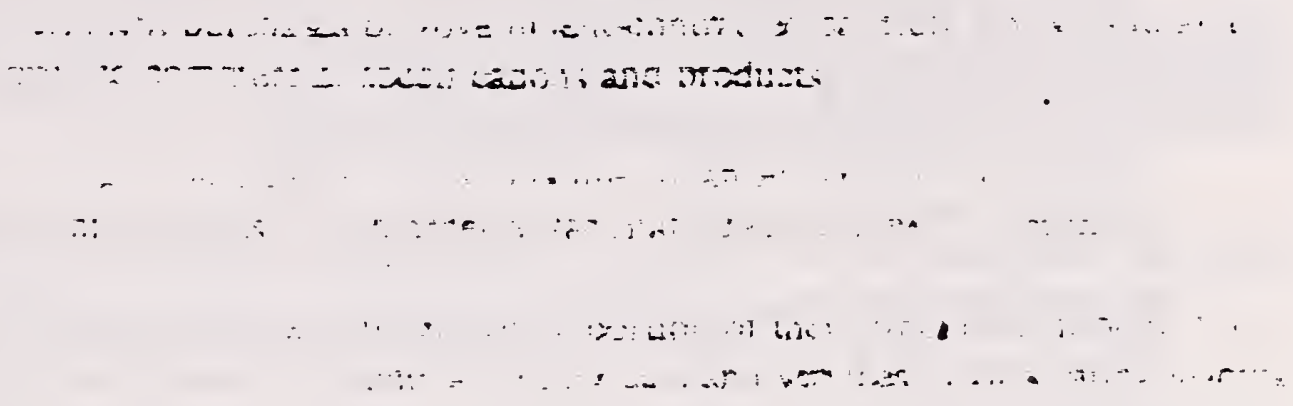


Increasing investment in civilian technologies is only one element of a strategy to restore America's industrial and technological leadership, and to create high-wage, high-shill jobs. The United States must also ensure that its tax, trade, regulatory and procurement policies encourage private sector ipvertment and innovation. In a global where capital and technology are increasingly mobile, the United States must make sure that it has the best environment for private sector investment and job creation.

To improve the environment for private sector investment and create jobs, we will:

1. Make Permanent the Research and Experimentation (R\&E) Tax Credit: The need for additional U.S. investment in R\&D is clear. Currently, the United States invests 1.9 percent of GDP in non-defense R\&D, as compared to 3.0 percent in Japan and 2.7 percent in West Germany. We will increase private R\&E expenditures by making the Research and Experimentation the credit.permanent. In the past, the effectiveness of this credit has been undermined by a series of six and nine-month temporary extensions. The credit cannot induce additional R\&E expenditures unless its future availability is known when the businesses are planning R\&E projects and projecting costs. R\&E activity, by its nature, is long term and businesses should be able to plan their research activity bnowing that the crectit will be available when the research is actually undertaken. Thus if the R\&E credit is to have the intended incentive effect, it should be permanent.

2. Create incentives for long-term investments in small businesses: The Administration will send legislation to Congress designed to provide incentives for those who make high-risk, long-term venture capital investments in startups and other small enterprises. These companies are the major source of job creation, economic growth, and technological dynamism in our economy.

3. Create incentives for investment in equipment: Currently, America's chief economic competitors are inverting twice as much in plant and equipment (as a percentage of GDP) as the United States. Furthermore, studies show a high correlation between investment in new equipment and productivity - since new technologies are often embodied in capital equipment. To stimulate additional investment in equipment, the Administration will propose a temporary incremental investment tax credit for large businesses and a permanent credit for small businesses.

4. Reform antitrust laws to permit joint production ventures: The Administration will forward legislation to Congress which would extend the National Cooperative Research Act of 1984 to cover joint production ventures. Increasingly, the escalating cost of stateof-the-ar manufacturing facilities will require firms to share costs and pool risiks.

5. Ensure that U.S. trade policy strengthens high technology industries: To remain competitive, America's high-tech industries need full access to overseas markets and effective protection of intellectual property rights. The Administration is committed to 
multilateral and bilateral negotiations, and enforcement of existing agreements, that will accomplish these objectives. The trade policy must also be consistent with a vigorous public research and development program.

6. Review proposals to increase the supply and avallability of patient capital: A number of proposals have been made to increase the time-horizon of investments. For example, the National Academy of Sciénce has proposed creating a publicly-funded, privately run Civilian Technology Corporation. The private-sector Council on Competitiveness has proposed a sweeping set of reforms to improve corporate governance and encourage long-term asset ownership. The Administration will review these and other proposals in an effort to improve the environment for long-term investments.

7. Ensure that federal regulatory policy encourages investment in innoration and technology development that achieve the purposes of the regulation at the lowest possible cost: Regulatory policy can have a significant impact on the rate of technology development in energy, biotechnology, pharmaceuticals, telecommunications, and many other areas. The caliber of the regulatory agencies can affect the international competitiveriess of the industries they oversee. At the same time, sbillful support of new technologies can help businesses reduce costs while complying with ambitious environmental regulations. A. well designed regulatory program can stimulate rather than frustrate attractive directions for innovation. We will review the nation's regulatory "infrastructure" to ensure that unnecessary obstacle's to technical innovation are removed and that priorities are attached to programs introducing technology to help reduce the cost of regulatory compliance.

\section{Education and Training}

Technology policy can play a key role in supporting our commitment to improving the education and training opportunities for all Americans.

First, it is essential that priorities in research, regulatory, and other policies designed to encourage innovation and investment in the economy reflect the need to create highperformance workplaces - workplaces which offer all workers skilled, rewarding jobs with opportunities for growth. These priorities are reflected in the design of the initiatives described earlies. Our plan ensures that economic growth works to the advantage of all Americans in the woriforce, not just an elite group of well-educated workers who have easy access to training in new sbills.

Secondly, it is essential that all Americans have access to the education and training they need and that the teaching enterprise itself become a high-performance worlplace. Our initiatives in edveation and training follow four central themes: restructuring primary and secondary schooling, using youth apprenticeships and other programs to facilitate the transioon from school to work for people who do not expect to go to college, making training accessible and affordable to all workers who need to upgrade their skills to keep pace with a rapidly 
changing economy, and programs specifically targeted to help workers displaced by declining defense budgets or increased intermational trade.

Technology policy an and must support all of these objectives.

1. Public investment will be provided to support tochnology that can increase the productivity of leaming atid techith in formaf school bettings, in industrial training, and even at home. New information technologies can give teachers more power in the classroom and create a new range of employment opportunities. Schools can themselves become high-performance workplaces.

2. Public investment will also be increased for programs designed to provide needed stalls in mathematics, science, and engineering. Programs will be supported in primary, secondary, college, post-graduate schools and in a range of industrial training facilities. Particular attention will be paid to increasing participation by minorities and women.

3. Defense capabilities in education and training represent an important resource. New programs will accelerate transfer of this experience to civilian institutions. The Department of Defense and NASA have inverted heavily both in the hardware and software needed for advanced instructional systems, they have accumulated valuable experience in how to use the new technologies in practical teaching situations. The Navy Training Systems Center and the Army Simulation, Training and Instrumentation Command together spend about $\$ 1$ billion a year on training systems. There are over 150 defense simulation and training companies serving these needs in central Florida alone.

Specific initiatives include the following:

A. Access to the Internet and developing NREN will be expanded to connect university campuses, community colleges, and K-12 schools to a high-speed communications network providing a broad range of information resources. Support will be provided for equipment allowing local networks in these leaming institutions access to the network along with support for development of high-performance software capable of taking advantage of the emerging hardware capabilities.

B. An interagency task force will be created from appropriate federal agencies to (i) ertablish software and communication standards for education and training, (ii) coordinate the development of critical software elements, (iii) support innovative software packages and curriculum design, and (iv) collect information resources in a standardized format and make them available to schools and teaching centers throughout the nation through both conventional and advanced communication networks. This task force will provide specific assistance to the interagency task force on worker displacement. 
C. Programs in the Federal Coordinating Council for Science, Engineering, and Technology (FCCSET) Committee on Education and Human Resources programs will be enhanced. These programs are designed to improve the teaching of science, mathematics, and engineering at all levels. In K-12 schools, primary emphasis will be placed on teacher preparation, comprehensive organizational reform, and curriculum development. Programs for undergraduate education emphasize faculty preparation and organization and curriculum reforms but place heaviest emphasis on student incentives. At the graduate level, -most funding is directed for fellowships.

D. Proposals will be encouraged for an industry consortia or regional alliance designed to develop new teaching systems (hardware and software) and work with training organizations throughout the nation to develop, install, and maintain state-of-the art systems. Firms now providing similar services to defense training organizations are likely to participate.

E. Promote Manufacturing Engineering Education. Traditional engineering education, with its focus on product design and analysis, has seriously neglected the management and operation of manufacturing activities. This program provides matching funds for graduate or undergraduate programs in manufacturing engineering. 


\section{New Options offered by Information Technology \\ in Education and Training}

- Computers can create en unprecedented opportunity for leaming complex ideas, creating an environment that can closely approximate real work environments or experimental apparatus.

- Interconnected systems can help.students work together as parts of a team even if the members of the team are separated geographically.

- Training can be embedded as a part of new equipment. Complex machine tools or software packages can be purchased, with tutorials that bring new operators up to speed quickly, that provide quick refreshers for unusual events, and that allow operators to build new competencies during off-hours. :

- Advanced systems permit instruction tuilored to the leaming needs of individuals. This is particularly important for retraining adults that reenter a training environment with a great variety of leaming needs and leaming abilities. And it is important in ensuring that minorities, women, people with disabilities, and others that may be disadvantaged by traditional approaches to instruction.

- Communication technologies can bring a rich education and training environment to people isolated because they live in remote areas or because of the demands of work and family responsibilities.

- Technology can reduce the burden of record-keeping and other paperwork that consumes so much teacher time in today's classrooms. It can also bring teachers and schools together in ways that facilitate the exchange of ideas and build a sense of community.

\section{"Information Superhighways"}

Efficient access to information is becoming critical for all parts of the American economy. Banks, insurance comparies, manufacturing concems, and many other business operations now depend on high-speed communication links. Many more businesses can take advantage of such systems if they are reliable, easy to use, and inexpensive. Such systems would also be of fnormous value to schools, hospitals, and other public organizations. Even the most remote school could be connected to state-of-the ar information. Hospitals could call in experts for consulation even if the expert is far from the patient.

Accelerating the introduction of an efficient, high-speed communication system can have the same effect on US economic and social development as public investment in the railroads had in the 19th century. It would provide a critical tool around which many new business opportunities can develop.

Specific new programs include : 
A. Implementation of the Bigh-performance Computing and Communications Program established by the High-Performance Computing Act of 1991 introduced by Vice President Gore when he served in the Senate. Research and development funded by this program is creating (1) more powerful super computers, (2) faster computer networks and the first national high speed network, and (3) more sophisticated software. This network will be construeted by the private sector but encouraged by federal policy and technology developments. In addition, it is providing scientists and engineers with the tools and training they need to solve "Grand Challenges", research problems-like modeling global warming-that cannot be solved without the most powerful computers.

B. Create a Task Force on Information Infrastructure. Governmént telecommunication and information policy has not kept pace with new developments in telecommunications and computer technology. As a result, government regulations have tended to inhibit competition and delay deployment of new technology. For instance, without a consistent, stable regulatory environment, the private sector will hesitate to make the investments necessary to build the high-speed national telecommunications network that this country needs to compete successfully in the 21st Century. To address this problem and others, we will create a high-level inter-agency task force within the National Economic Council which will work with Congress and the private sector to find consensus on and implement policy changes needed to accelerate deployment of a national information infrastructure.

C. Create an Information Infrastructure Technology Program to assist industry in the development of the hardware and software needed to fully apply advanced computing and networking technology in manufacturing, in health care, in life-long learning, and in libraries.

D. Provide funding for networking pilot projects through the National Telecommunications and Information Administration (NTIA) of the Department of Commerce. NTIA will provide matching grants to states, school districts, libraries, and other non-profit entities so that they can purchase the computers and networking connections needed for distance leaming and for hooking into computer networks like the Internet. These pilot projects will demonstrate the benefits of networking to the educational and library communities.

E. Promote dissemination of Federal information. Every year, the Federal government spends billions of dollars collecting and processing information (e.g. economic data, environmental data, and technical information). Unfortunately, while much of this information is very valuable, many potential users either do not know that it exists or do not know how to access it. We are committed to using new computer and networking technology to make this information more available to the taxpayers who paid for it. In addition, it will require consistent Federal information policies designed to ensure that Federal information is made available at a fair price to as many users as possible while encouraging growth of the information industry. 
Iransportation and other Infrastoucture

A competitive, growing economy requires a transportation system that can move people, goods and services quickly and efficiently. To meet this challenge, each transport sector must work effectively both by itself and as part of a larger, interconnected whole. With nearly one out of every six dollars of GDP now spent th transportation related activities, vechnologies that increase the speed, reliability, and cost-effectiveness of the transportation sector will also increase the economy's competitiveness and ability to create jobs.

One of the greatest challenges we face is to rehabilitate and properly maintain the huge stock of infrastructure facilities already in place. With this in mind, the Administration will consider establishing an integrated program of research designed to enhance the performance and longevity of the existing infrastructure. Among other things, this program would systematically address issues of assessment technology and renewal engineering. A strategic program to develop new technologies for assessing the physical condition of the nation's infrastructure, together with techniques to repair and rehabilitate those structures, could lead to more cost-effective maintenance of the infrastructure necessary to economic growth.

Providing a worid class transportation sector will require the nation to meet the challenges posed both by increased congestion in many parts of the transportation system, and by the need to rebuild and maintain a public capital stock valued at more than \$2.4 trillion. To meet these challenges, the Administration's program includes increased investment in a number of areas:

A. Upgrading the nation's high rays and transit systems by providing additional funding authorized by the Intermodal Surface Transportation Efriciency Act of 1991 (STEA). Improve mass transit services and facilities by investing an additional \$600 million in 1994 and $\$ 1$ billion each year from 1995 to 1998 in transit capital projects.

B. Investing in magnetic levitation (maglev) transportation and high-speed rail by providing funds for a maglev prototype and for start-up of private or state/local highspeed rail projects.

C. Increasing research on ner technologies that could lead to the development of "smart highways". These effors range from technologies that provide in-route planning and traffic monitoring, to those that would support a fully automated system.

D. Increasing research on civil aviation technologies, including an examination of the economic, market, safety, and noise aspects of advanced aireraft. We will also support advanced in-flight space and ground-based command, navigation, weather prediction, and control systems. US aeronautical, research and development facilities infrastructure such as wind tunnels will also be revitalized. 
E. Increasing research on Dew materials that will allow the construction of infrastructure facilities that are more durable, minimizing the frequency of costly reconstruction with its attendant disruption of traffic.

F. Exploring new astessment technologies for borteccurately assessing the expected life of existing public infrastructure. A number of new technologies from a variety of industries, including électronic, medical, space, defense, and manufacturing sectors, could be used to develop more-reliable, nondestructive methods for evaluating the condition of existing structures. Since current àssessment techniques are so unreliable, engineering decisions must include significant room for error and costly fail-safe features. The data made available by nondestructive evaluation and monitoring could be used to schedule better an ongoing program of cost-effective mainitenance and rehabilitation.

G. Supporting renewal engineering programs which target materials and construction methods that would lower the cost of rehabilitating and repairing structures. 
The federal government must use technology to improve the efficiency of its own operations: : Many private businesses have used advanced communication systems to improve the efficiency of their operations and to make their businesses more sensitive to the needs of individual customers and clients. The federal government must move actively to take advantage of these new opportunities. Similarly, the federal government is one of the nation's largest consumers of energy yet many of its buildings are far less efficient than structures owned by private firms and taxpayers are paying the bill.

The enormous purchasing power of the federal government can be used to stimulate markets for innovative products in many areas. This power should be exercised in a way that is consistent with overall national technology objectives. President Clinton is committed to reinventing government, to make government work better, harder, and smarter. Technology an help us achieve that goal.

\section{Information Technology}

Information technology will be used to dramatically improve the way the Federal Government serves the people. Government will become more cost-effective, efficient, and "user-friendly." In particular, we will use technology to improve the quality and timeliness of service, to provide new ways for the public to communicate with their government, and to make government information available to the public in a timely and equitable manner.

Fast communication makes it possible for teams to work closely on a project even if the team members are physically distant from each other. Information technology presents an opportunity to flatten existing organizational structures, form effective cross-disciplinary problem-solving groups, and expand the definition of the workplace and worlforce via telecommuting. But business organizations in many sectors have found that automating existing work processes based on a tradition of processing paper does not always provide the greatest benefits from investment in automation. Efficiency gains from the new technology ofien can only be captured if changes are made in the structure of their organizations and the way they are managed. The administration will undertake a careful review of government management with a view to making the most efficient possible use of new information technologies.

Improved guality and timeliness of service. Information technology will eliminate errors generaled in routine paper processes while reducing processing time. For example, the Intemal Revenue Service (IRS)'s electronic filing program is reducing error rates on tax returns from 16 percent to less than 3 percent, while speeding up the delivery of refunds by as much as four weeks. Agencies are moving forward to convert many other paper processes to electronic form.

Information on paper is hard to retrieve. Automation is allowing the Social Security Administration to provide beneficiaries with "one-stop" service anywhere in the country from 
an 800 number. Better connections among Federal offices, in a manner that safeguards the privacy of individuals, will make it easier to get answers from the government.

New ways to communicate. In the part, citizens typically had to go to a federal office during business hours to receive benefits or services, A government that uses technology to expand its hours of service and communicate with the public electronically will deliver services and benefits where people need them, oot where the government provides them. We will make it possible for people to communicate with a Federal agency using electronic as well as conventional mail. Automated terminals may be placed in public tocations such as shopping centers or post offices that could provide in-hours access to 2 variety of government services.

Access to government information. Government information is a public asset. Markets depend on sound and timely economic decisions. Federal geographic and climatological information allows farmers to apply fertilizer more efficiently; - local governments to formulate environmental policy, and public safety officials to prepare for natural disasters. The government will promote the timely and equitable access to government information via a ${ }^{2}$... diverse array of sources, both public and private, including state and-local governments and libraries. The development of public networks such as the Internet and the National Research and Educational Network (NREN) will contribute significantly to this diversity, enabling government information to be disseminated inexpensively to a broad range of users.

Policy and technology infrastructure. Many of the government's policies in such areas as privacy, information security, records management, information dissemination, and $\pi$ procurement will be updated to take into account the rapid pace of technological change. In addition, the government must apply the economic principle of maximizing retum on investment when acquiring information technology, and be able to acquire commercial, offthe-shelf technology quickly and easily.

In addition, resources are needed to provide a technology infrastructure to support these service delivery improvements. The support for the IRS Tax System Modernization in the stimulus paciage, along with requests elsewhere for resources to support information technology, are examples of the government investing in tochnology to put people first.

\section{Energy Efficiency}

The federal government is wasting tax dollars by operating inefficient buildings. More than $\$ 2$ billion could be invested in energy retrofits in federal buildings with average payback times less than 3-4 years. Califomia, Texas, Iowa, and several other states have successful programs which have profitably inverted in state buildings during the past several years. The programs have both increased the efficiency of state structures and stimulated the local construction industry.

HUD spends approximately $\$ 3-4$ billion a year subsidizing the energy bills of about 5 million low income households. At least $\$ 3$ billion could be invested in energy retrofits with a payback less than five years. 
We are introducing a multi-year program designed to capture the economic benefits of energy retrofits, create new jobs in the construction industry, and to foster innovation in efficient building components and in the construction industry itself.

\section{Brocurement Policy}

The federal government, particularly the Department. of Defense and NASA, is a gigantic customer for high technology products. Historically, it played an important role in helping assure an early market for high-risk commercial technologies that were extremely expensive to develop. For example, the defense-space share of the U.S. computer hardware market was 100 percent in 1954, and it exceeded 50 percent until 1962. Semiconductors, jet aircraft, and pharmaceuticals also benefited from this government investment.

In recent years, DoD has ceased to be an influential "first customer" for commercial technology. By and large, this is nof dive to differing technical requirements: today's commercial capabilities often equal or surpass DOD requiremients. Rather the problem is a growing morass of procurement laws and regulations. Mariy commercial manufacturers refuse to do business with DOD altogether, and those that do often wall off their defense production. As a result, the military and commercial worlds have grown increasingly segregated from one another.

The cost of this segregation both to DOD and the nation is high, as a 1991 report by the Center for Strategic and International Studies plainly stated:

"[It] results in higher prices to DOD (even when lower-cost commercial alternatives exist for the same requirements), loss of a broad domestic production base that could be available to defense for peacetime and surge demands, and lack of access to commercial state-of-the-art technologies. Additionally, the wall between engineers and scientists engaged in commercial and military work impedes the kind of shoulder-toshoulder contact that is the essence of technology transfer and that is basic to achieving greater job stability and growth opportunities for the U.S. work force."

The federal government will make it a priority to thoroughly review and reform its procurement policy, particularly (but not exclusively) defense procurement policy. It will begin by reviewing the recommendations of the congressionally-mandated "Section 800 Panel" (after Section 800 of the FY1991 Defense Authorization Act), which recently completed a detailed study of DOD procurement practices. 
More specifically, the federal government will begin steps necessary to achieve the following reforms:

-... Government purchases or $80 v e m$ ment-contracted development should give priority to commercial specifications and products.....

- Agencies should invest in and procure advanced technologies, where it is conomically feasible, in order to facilitate their commercialization.

- Agencies should experiment with a portion of their procurement budget to allow them to procure innovative products and services incorporating leadingedge technologies.

- Agencies should evaluate bids based on their ability to minimize life-cycle cost rather than acquisition cost, including environmental, health and safety costs borne by the public.

- Agencies should obtain rights in technologies developed under government contracts only to the extent necessary to meet the agencies' needs, leaving contractors with the rights necessary to encourage private sector investment in the development of commercial applications.

- Agencies should use performance-based contracting strategies that give contractors the design freedom and financial incentive to be innovative and efficient. 


\section{GOAL: WORID LEADERSEIP IN BASIC SCIENCE, MATHEMATICS, AND ENGINEERING.}

It is essential to recognize that technical advances depend on basic research in science, mathematics, and engineering. Scientific advances are the wellspring of the technical innovations whose benefits are sen in economic growth, improved health care, and many other areas. The federal government has invested heavily in basic research since the Second World War and this support has paid enormous dividends. Our research universities are the best in the world; our national hboratories and the research facilities they house attract scientists and engineers from around the globe. In almost every field, United States researchers lead their foreign colleagues in scientific citations, in Nobel Prizes, and most other measures of scientific excellence.

This administration will both ensure that support for basic science remains strong, and that stable funding is provided for projects that require continuity. We will not allow shortterm fluctuations in funding levels to destroy critical research teams that have taken years to assemble.

But stable funding requires setting clear priorities. In recent years, rather than canceling less important projects when research budgets have been tight, Federal agencies have tended to spread the pain, resulting in disnuptive cuts and associated schedule delays is:" = hundreds of programs. We will improve management of basic science to ensure that highpriority programs receive sustained support.

University Research. The National Science Foundation and the National Institutes of Health provide the vast majority of Federal funding for university research. Since universities play dual roles of research and teaching, the long-term scientific and technological vitality of the U.S. depends upon adequate and sustained funding for university research grant programs at NSF, NIH, and other research agencies.

National Laboratories. In fields like high-energy physics, biomedical science, nuclear physics, materials sciences, and acronautics, the national laboratories provide key facilities used by researchers in academia, Federal labs, and industry. In addition, in many fields, researchers at Federal labs are world leaders. We will ensure that Federal haboratories continue their key role in basic research and will encourage more cooperative research between the laboratories and industry and universities. And we will develop new missions for our federal labs to make full use of the talented and experienced men and women working there in today's post-cold war era.

Space Science and Exploration. The resources needed for space exploration and research make government funding essential. We will continue to work with foreign partners to design missions needed to explore our solar system and the universe beyond. Research on micro-gravity and life-sciences as applied to the human in space program will also be suppored. 
Environmental Research. In FY93, the Federal government will invest in research to better understand global warming, ozone depletion, and other phenomena important to local, regional, and global environments. This research is essential if we are to fully assess the damage mankind is doing to our planet and take effective action to address it. Vital research on local and regional environmental problems will also be strongly supported at EPA, NOAA, NASA, DOD, DOL, USDA, and other agencies. 
BUIDDNG AMIERICA'S ECONOMIC STRENGTH: NEW INITLTIVES

- : Permanent Extension Or The Resench And Experimentation Tax Credit

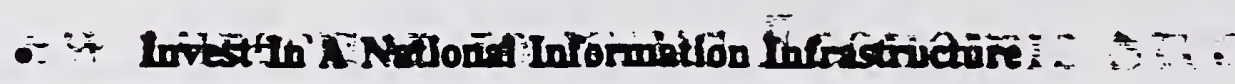

- Advanced Manufacturing Technology

- Facilitate Private Sector Development of a New Generation of Automobiles

- Improve Technology För Educition And Training

- Investments In Energy-Ericient Federral Buildings 
0.27 missing 


\section{INVEST IN AN INFORMATION INFRASTRUCTURE}

\section{Qbiectives}

Today's "Information Age" demands abill, apility and speed in moving information. Where once our economic trength was determined solely by the depth of our ports or the condition of arr roads, way it is determined as well by our ability to move lage quantities of information quickly and courately and by our ability to use and undersand this information. Just as the intersate highway system marked a historial tuming point in our commerce, today "information supertighway" - able to move idas, data, and images around the country and around the world are critical to American competitiveness and economic atrength.

This information infrestructure - computers, computer dan benis, fix machines, telephones, and video displays - has as its lifeline a high-speed fiber-optic setwork capable of transmitting billions of bits of information in a second. Imagine being able to transmit the entire Encyclopedia Britanica in one seoond.

The computing and networking technology that makes this possible is improving it an unprecented rate, expanding both our imapinations for its use and its effectiveness. Through these technologies, a doctor who needs a second opinion could transmit a patient's entire medial record - $x$-rays and ultracound seans included - to a colleague thoueands of miles away, in less time than it thes to send a fax boday. A school child in a small town could come home and through a personal computer, reach into an electronic Library of Congress - thousands of books, records, videos and photographs, all stored electronieally. At home, viewers could choose whenever they wanted from thousands of different television programs of movies.

Efficient acess to information is becoming incresingly more important for all parts of arr economy. Bante, insurance companies, manufacturing concems, and many other businesses now depend on high speed communiation nerworts. These networbs hrve becorme a critial bol around which many new business opportunities are developing.

And, by hamescing the power of aipercomputers able to transform enormous amounts of information to imates or solve incredible complex problems in record time, and share this power with an everexpanding audience of scientists, businesees, researchers, sudents, doctors and others, the potential for innovation and progress multiplies rapidly. Supercomputers belp us develop new drigs, design new products, prediet dangerous storms and model climate changes. They help us design better ears, beter aiplanes, more efficient manuficturing proceses. Acolerating the introduction of an efficient, high-speed communiation network and arociated computer systems would have a dramatic impact on every 'aspect of our lives. Bun this is possible only if we adopt forwart-bookins policies thas promote the development of new thechnologies and if we invert in the information infrastructure needed for the 2lat Century. 
A. Implementation of the High-perforiance Computing and Communications Program established by the High-Performance Computing Act of 1991 introduced by Vice President Gore when he served in the Senate. Research and development funded by this program is crating (1) more poiverful super coinpuiters, (2) faster computer networks and the first national high speed network, and (3) more sophisticated software. This network will be constructed by the private sector but encouraged by federal policy and technology developments.- In eddition; it is providing scientists and engineers with the tools and training they need to solve "Gránd Challenges", research problems-like modeling global waming - that cannot be solved without the most powerful computers.

B. Create a Task Force on Information Infrestructure. Govemment telecommunication and information policy has not kept pace with new developments in telecommunications and computer technology. As a result, government regulations have tended to inhibit competition and delay deployment of new technology. For instance, without a consistent, stable regulatory environment, the private sector will hesitate to make the investments necessary to build the high-speed national telecommunications network that this country needs to compete successfully in the 21st Century. To address this problem and others, we will create a high-level inter-agency task force within the National Economic Council which will work with Congress and the private sector to find consensus on and implement policy changes needed to accelerate deployment of a national information infrastructure.

C. Create an Information Infrastructure Technology Program to assist industry in the development of the hardware and software needed to fully apply advanced computing and networking technology in manufacturing, in health care, in life-long leaming, and in libraries.

D. Provide funding for networking pilot projects through the National Telecommunications and Information Administration (NTLA) of the Department of Commerce. NTIA will provide matching grants to states, school distriets, libraries. and other non-profit entities so that they can purchase the computers and networking connections needed for distance leaming and for hooking into computer networks like the Internet. These pilor projects will demonstrate the benefits of networking to the educational and library communities.

E. Promote dissemination of Federal information. Every year, the Federal government spends billions of dollars collecting and processing information (e.g. economic data. environmental data, and technical information). Unfortunately, while much of this information is very valuable, many potential users either do not bnow that it exists or do not know how to access it. We are committed to using new computer and networking technology to make this information more available to the taxpayers who paid for it. In addition, it will require consistent Federal information policies designed 
to ensure that Federal information is made available at a fair price to as many users as possible while encouraging growth of the information industry. 


\section{PROMOTE ADVANCED MANUFACTURNG TECENOLOGY}

\section{Objectives}

Manufacturing remains the foundation of the Amerian economy. Nithough the United States was the unchallenged world leader in manufacturing for many years, our performance has slipped badly in recent decades. American firms still excel at making brealthroughs, such as IBM's discovery of high-temperanure superconductivity, but foreign firms are often better at follow through: namely, turning technology into new products and processes both quickly and cheaply.

Both Amerian industry and government under-invest in manufacturing. In contrast to their foreign competitors, U.S. firms neglect process-related R\&D within their overall R\&D portfolio. And the federal government allocated only two percent of its $\$ 70$ billion R\&D budget to manufacturing R\&D in FY92.

We have also neglected the dissemination of existing technology and know-how. New manufacturing technologies and approaches are available that can lead to dramatic improvements in product quality, cost, and time-to-market. Although a few U.S. firms have begun to adopt these technologies and approaches, most firms still lag. The problem is most acute among the 360,000 small and medium-sized manufacturers, who employ 8 million workers, but too often lack the resources or ability to gain access to the technologies that will help them grow, increase their profits, and create jobs.

Finally, investments in manufacturing have not reflected the concerns and the knowledge of factory employees. Firms should use technology to build on rather than reduce worker stalls.

\section{Actions:}

A. Provide increased funding for advanced manufacturing R\&D. SEMATECH, an industry consortium to develop semiconductor manufacturing technology, will receive continued matching funds from the Department of Defense in FY94. Industry consortia (including universities and government laboratories, where appropriate) will be the preferred performers of such R\&D, to assure its commercial relevance. Programs will be encouraged in the development of a new automobile, new construction technologies, intelligent control and sensor technologies, rapid prototyping, and environmentallyconscious manufacturing. 
B. Support Agile Manufacturing. The dew Agile Manufacturing Program (also bown as "Enterprise Integration") is designed to capitalize on the emerging shift from mass production to flexible or "agile" manufacturing. Agile manufacturing allows independently-owned companies to form instantaneous partnerships with firms that have complementary capabilities in order to exploit market opportunities. These partnerships - called "virtual enterprises" or "virtual corporntions" - will levertige our mintion's "." wrengths in information technology, This program upports both the development and discemination of such technology for enterprise integration.

C. Create a mationd inetwork of manufacturing extension centers. Many amall and medium-sized manufacturing firms in the U.S. have not then advantage of new technologies and best practices, either because they are thaware of them or beciuse they cannot afford therri:- Existing state and federl minnufactiring extiension centers provide assistance to a small number of firms, but service must be greatly expanded to give all firms access to the technologies, testing facilities, and training programs they need. Federal funds (to be matched by state and loeal governments) will go to support and build on existing state, local, and university programs, with the goal of crating a mation-

- wide network of extension centers.

D. Seed Regional Technology Allinoces. Manufacturing industries tind io cluster geographially, and the strength of these technology clusters is fast becoming a key to international competitiveness. This new program is designed to encourage firms and research institutions in a paricular region to exchange information, share and develop technology, and develop new products and markets. Federal funds (to be matched by alliance members) will go to support applied R\&D and a range of technology services oriented particularly to smalles firms (ter freilities for new products and prototypes, design and management ascistance, start-up incubators, edueation and trining, export promotion and market monitoring, and quality resting and standards certification).

E. Promote Manufacturing Engineering Education. Triditional engineering educition, with its focus on product decign and analysis, has seriously neglected the management and operation of manufacturing activities. This program provides matching funds for graduate or undergraduate programs in manufzeturing engineering.

F. Promote Environmentally-Conscious Manufacturing. The Departments of Commerce, Energy, Defense, and a number of other federd organizations will incorporate environmental goals in research and development consortin for manufacturing. In addition, NIST, working with EPA, DOE, and state agencies, will undertake a technial support program in energy and environmental waste minimization for small and medium-sized firms. 
FACIITATE PRIVATE SECTOR DEVELOPMENT OF A NEW GENERATION OF AUTOMOBILES

Objectives:

The automobile plays a central role in U.S. 'manufacturing capabilities, in America's conomy, and in the lives of most Americans. If America's auto industry is to remain competitive and strong in the 21st century, preserving jobs, sustaining economic growth, and expanding its business, it must continue its exploration of new technologies that encournge the industry's growth and protect the environment. 'Increvsingly stringentienvironmental concerns both here and abroad make this effort increasingly more esential and the need for innovation and new ideas even greater.

New fuels and new propulsion systems developed during the last decade offer promise as eventual replacements for the combination of gasoline and the interinal combustion engine that have served so well for generations. Given adequate investment in research and development, and adequate incentives for U.S. producers to invest in these technologies, a new generation of vehicles could be on the market - preserving jobs, expanding growth - that would be safe and perform as well, if not better than existing automobiles, cost no more to drive than today's automobiles, consume only domestic fuels such as natural gas and renewables, and produce litle or no pollution.

While the basic technology needed to achieve this goal is available, converting it to a practical vehicle represents an historic challenge. The potential can only be captured under the leadership of the U.S. business community and the industry itself. Success must be defined by their ability to develop a vehicle that can be built and sold successfully in private markets. They must play a central role in designing an efficient government-industry partnership in which the industry plays a leadership role in establishing priorities.

If U.S. producers lead the worid in introducing such a vehicle, the domestic industry would be able to meet expanding domestic and intemational markets with a machine that significantly reduces pollution and operates from domestic fuel sources.

This initiative represents a bold and dramatic step toward a more profitable, and more environmentally sound future for one of America's most important industries. 
A. Establich a "clean car" task force linking research efforts of relerant agencies with those of U.S. auto manufacturers. This tost force will immediately establish an advisory group zonsisting of technology lendersin the principle. US qutomobile manufacturers, their principel erppliens; and US fuel suppliers. If will oversee the .... establishment of cooperative recench ventives in (i) frut-alle and the control and ocher systems required for practiol fuel-cell hybrid vehicle designs, (ii) edvanced batteries, ultra-capacitors, advaneed gas storage-\& delivery systems, and (iii) production of .methanol and hydrogen from naturl gas, municipal waste and other waste products, energy crops, and the electrolysis of water

B. The task force will establish a special advisory group consisting of ky sorte officials and representatives of the participiting Dejertments to (a) designi a propram for using the authority already present-in the Clean Air-Act revision of 1991 and the National Energy Act of 1992 to encournge introduction of prototype vehicles consistent with the objectives of this program, (ii) coordinate state regulatory programs designed to require low or zero emission vehicles, and (iii) propose federal regulations needed to supplement state efforts. It will also design programs for managing federal vehicle procurement.

C. Working with its private sector and state advisory groups, the task force will prepare a list of derelopment requirements and condact a systematic search for capabilities in national laboratories and defense facilities. Capabilities identified will be integrated rapidly into the research terms. 


\section{IMPROVE TECENOLOGY FOR EDUCATION AND TRAINING}

\section{Objectives}

This project will support the development and introduction of computer and communications equipment and software that cân încresse the productivity of leaming in formal school settings, a variety of business training facilities, and in homes.

Actions

A. Access to the Internet and developing high-speed National Research and Educational Network (NREN) will be expanded to connect university ampuses, community colleges, and K-12 schools to a high-speed communications network providing a broad range of information resources. "Suppoif will be provided for equipment allowing local networks in these leaming institutions access to the network along with support for development of high-performance software capable of taking advantage of the emerging hardware capabilities.

B. An interagency task force will be created from appropriate federal agencies to (i) adopt software and communication standards for education and training, (ii) coordinate the development of critical software elements, (iii) support innovative software packages and curriculum design, and (iv) collect information resources in a standardized format and make them available to schools and teaching centers throughout the nation through both conventional and advanced communication networks. This task force will provide specific assistance to the interagency task force on worker displacement.

C. Programs in the Federal Coordinating Council for Science, Engineering, and Technology (FCCSET) Committee on Education and Human Resources programs will be enhanced. These programs are designed to improve the teaching of science, mathematics, and engineering at all levels. In K-12 schools, primary emphasis will be placed on teacher preparation, comprehensive organizational reform, and curriculum development. Programs for undergraduate education emphasize faculty preparation and organization and curriculum reforms but place heaviest emphasis on student incentives. At the graduate level, most funding is directed for fellowships.

D. Proposals will be encouraged for an industry consortin or regional alliance designed to develop Dew teaching systems (hardware and software) and work with training organizations throughout the nation to develop, install, and maintain state-of-the ar systems. Firms now providing similar services to defense training organizations are likely to participate.

E. Promote Manufacturing Engineering Education. Traditional engineering education. with its focus on product design and analysis, has seriously neglected the management and operation of manufacturing activities. This program provides matching funds for graduate or undergraduate programs in manufacturing engineering. 
Obiectives

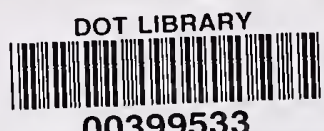

This project would increase the efficiency of goverrment by making cost-effective invertments in buildings where the energy bills are paid by the texpayers. The project would create a significant number of jobs in utban areas, create new businesses and job skills, stimulate maikets for innoviative thergy efficiency equipment, and reduce the impact of the federd government on the environment.

Actions

In the case of federal building retrofits, funding will be provided to the Department of Energy which will be responsible for managing the program.

In the ase of funds for federally subsidized housirg; 'funds will be provided to HUD which will manage the fund with DOE providing technical guidarice:

A. Create an advisory group of key officials from states with successful state building retrofit programs, representative building facility managers from federal buildings, and utility managers of successful "demand-side management" programs. - This group will ensure that the federal program is designed with the advantage of their experience and provide periodic evaluation and guidance.

B. The managers of the funds will provide funding for preliminary "walk through" audits, following the experience in the Texas program. Based on these preliminary studies, funding will be provided for more extensive audits. Proposals made in these audits will be funded using the following criteria:

- technical merit of the proposal;

- extent to which all cost-effective avings (i.e. justified on a $10 \%$ ral discount rate) have been coptured;

- cost-sharing by the agency, utility, or ocher source of financing;

- in the case of federally subsidized housing, sate and other non-program costsharing will be considered, including use of Low-Income Home Energy Assistance Program (LIREAP) and other funds - at least a 1:1 match should be expected; and

- the extent to which contractors invest in hiring and training new workers.

In each proposal, at least 6\% of the program cost will be set aside for monitoring and evaluation using regional centers that follow an agreed protocol established by a lead center

Up to 10\% of the program funds should be spent to create early markets for innovative technologies which represent a significant advance over existing systems and have the potential for large future applications. 